Functions. The objectives of the ACS are enshrined in the Convention and are based on the following: the strengthening of the regional co-operation and integration process, with a view to creating an enhanced economic space in the region; preserving the environmental integrity of the Caribbean Sea which is regarded as the common patrimony of the peoples of the region; and promoting the sustainable development of the Greater Caribbean. Its current focal areas are trade, transport, sustainable tourism and natural disasters.

Organization. The main organs of the Association are the Ministerial Council and the Secretariat. There are Special Committees on: Trade Development and External Economic Relations; Sustainable Tourism; Transport; Natural Disasters; Budget and Administration. There is also a Council of National Representatives of the Special Fund responsible for overseeing resource mobilization efforts and project development.

Headquarters: ACS Secretariat, 5-7 Sweet Briar Road, St Clair, PO Box 660, Port of Spain, Trinidad and Tobago.

Website: http://www.acs-aec.org

e-mail: mail@acs-aec.org

Secretary-General: Dr Rubén Arturo Silié Valdez

(Dominican Republic).

\section{Caribbean Community (Caricom)}

Origin. The Treaty of Chaguaramas establishing the Caribbean Community and Common Market was signed by the prime ministers of Barbados, Guyana, Jamaica and Trinidad and Tobago at Chaguaramas, Trinidad, on 4 July 1973.

Six additional countries and territories (Belize, Dominica, Grenada, St Lucia, St Vincent and the Grenadines, Montserrat) signed the Treaty on 17 April 1974, and the Treaty came into effect for those countries on 1 May 1974. Antigua acceded to membership on 4 July that year; St Kitts and Nevis on 26 July; the Bahamas on 4 July 1983 (not Common Market); Suriname on 4 July 1995.

Members. Antigua and Barbuda, Bahamas, Barbados, Belize, Dominica, Grenada, Guyana, Haiti, Jamaica, Montserrat, St Kitts and Nevis, St Lucia, St Vincent and the Grenadines, Suriname, and Trinidad and Tobago. Anguilla, Bermuda, the British Virgin Islands, Cayman Islands and Turks and Caicos Islands are associate members.

Objectives. The Caribbean Community has the following objectives: improved standards of living and work; full employment of labour and other factors of production; accelerated, co-ordinated and sustained economic development and convergence; expansion of trade and economic relations with third States; enhanced levels of international competitiveness; organization for increased production and productivity; the achievement of a greater measure of economic leverage and effectiveness of member states in dealing with third States, groups of States and entities of any description; enhanced coordination of member states' foreign and foreign economic policies; enhanced functional co-operation.

At its 20th Meeting in July 1999 the Conference of Heads of Government of the Caribbean Community approved for signature the agreement establishing the Caribbean Court of Justice. They mandated the establishment of a Preparatory Committee comprising the Attorneys General of Barbados, Guyana, Jamaica, St Kitts and Nevis, St Lucia and Trinidad and Tobago assisted by other officials, to develop and implement a programme of public education within the Caribbean Community and to make appropriate arrangements for the inauguration of the Caribbean Court of Justice prior to the establishment of the CARICOM Single Market and Economy. To this end at its 23rd Meeting in July 2002 the Heads of Government agreed on immediate measures to inaugurate the Court by the second half of 2003, although delays meant it was not inaugurated until April 2005. Among the measures adopted was the establishment of a Trust Fund with a one-time settlement of US\$100m. to finance the Court. The President of the Caribbean Development Bank was authorized to raise the funds on international capital markets, so that member states could access these funds to meet their assessed contributions towards the financing of the Court. The agreement establishing the Regional Justice Protection Programme was also approved for signature. The agreement establishes a framework for regional co-operation in the protection of witnesses, jurors, judicial and legal officers, law enforcement personnel and their associates.

Structure. The Conference of Heads of Government is the principal organ of the Community, and its primary responsibility is to determine and provide the policy direction for the Community. It is the final authority on behalf of the Community for the conclusion of treaties and for entering into relationships between the Community and international organizations and States. It is responsible for financial arrangements to meet the expenses of the Community.

The Community Council of Ministers is the second highest organ of the Community and consists of Ministers of Government responsible for Community Affairs. The Community Council has primary responsibility for the development of Community strategic planning and co-ordination in the areas of economic integration, functional co-operation and external relations.

The Secretariat is the principal administrative organ of the Community. The Secretary-General is appointed by the Conference (on the recommendation of the Community Council) for a term not exceeding five years, and may be re-appointed. The Secretary-General is the Chief Executive Officer of the Community and acts in that capacity at all meetings of the Community Organs.

Associate Institutions. Caribbean Development Bank (CDB); University of Guyana (UG); University of the West Indies (UWI); Caribbean Law Institute (CLI)/Caribbean Law Institute Centre (CLIC); Secretariat of the Organisation of Eastern Caribbean States.

Official language: English.

Headquarters: Bank of Guyana Building, PO Box 10827,

Georgetown, Guyana.

Website: http://www.caricom.org

Secretary-General: Edwin W. Carrington (Trinidad and Tobago).

Publications. CARICOM Perspective (1 a year); Annual Report; Treaty Establishing the Caribbean Community; Caribbean Trade and Investment Report 2000.

\section{Further Reading}

Parry, J. H., et al. A Short History of the West Indies. Rev. ed. London, 1987

\section{Caribbean Development Bank (CDB)}

Established in 1969 by 16 regional and two non-regional members. Membership is open to all states and territories of the region and to non-regional states which are members of the UN or its Specialized Agencies or of the International Atomic Energy Agency. 